\title{
Diagnostic Features of Common Oral Ulcerative Lesions: An Updated Decision Tree
}

\author{
Hamed Mortazavi, ${ }^{1}$ Yaser Safi, ${ }^{2}$ Maryam Baharvand, ${ }^{1}$ and Somayeh Rahmani1 \\ ${ }^{1}$ Department of Oral Medicine, School of Dentistry, Shahid Beheshti University of Medical Sciences, Tehran, Iran \\ ${ }^{2}$ Department of Oral and Maxillofacial Radiology, School of Dentistry, Shahid Beheshti University of Medical Sciences, Tehran, Iran \\ Correspondence should be addressed to Maryam Baharvand; m-baharvand@sbmu.ac.ir
}

Received 1 July 2016; Accepted 7 September 2016

Academic Editor: Giuseppina Campisi

Copyright (c) 2016 Hamed Mortazavi et al. This is an open access article distributed under the Creative Commons Attribution License, which permits unrestricted use, distribution, and reproduction in any medium, provided the original work is properly cited.

Diagnosis of oral ulcerative lesions might be quite challenging. This narrative review article aims to introduce an updated decision tree for diagnosing oral ulcerative lesions on the basis of their diagnostic features. Various general search engines and specialized databases including PubMed, PubMed Central, Medline Plus, EBSCO, Science Direct, Scopus, Embase, and authenticated textbooks were used to find relevant topics by means of MeSH keywords such as "oral ulcer," "stomatitis," and "mouth diseases." Thereafter, English-language articles published since 1983 to 2015 in both medical and dental journals including reviews, meta-analyses, original papers, and case reports were appraised. Upon compilation of the relevant data, oral ulcerative lesions were categorized into three major groups: acute, chronic, and recurrent ulcers and into five subgroups: solitary acute, multiple acute, solitary chronic, multiple chronic, and solitary/multiple recurrent, based on the number and duration of lesions. In total, 29 entities were organized in the form of a decision tree in order to help clinicians establish a logical diagnosis by stepwise progression.

\section{Introduction}

Ulcerations are characterized by defects in the epithelium, underlying connective tissue, or both. Due to diversity of causative factors and presenting features, diagnosis of oral ulcerative lesions might be quite challenging [1-4]. This narrative review paper, however, focuses on the duration and the number of lesions in order to build a diagnostic decision tree.

For the purpose of this article, if an ulcerative lesion lasts for two weeks or longer, it is considered chronic; otherwise, it is regarded as an acute ulcer [1,2]. Recurrent ulcers, on the other hand, present with a history of similar episodes with intermittent healing [3]. The term solitary indicates the presence of a single ulcerative lesion whereas the term multiple describes the presence of several ulcerative lesions [5]. In order to arrive at a definitive diagnosis, it is imperative to consider differential diagnoses. This is the cognitive process of integrating logic and knowledge into a series of stepwise decisions. All lesions that cannot be excluded initially should be included in the differential diagnosis, followed by laboratory tests and additional investigations to narrow the diagnosis. According to the literature, many cases of oral malignant ulcerations were misdiagnosed as nonneoplastic lesions up to several months before the definite diagnosis was established [6-8]. Valente et al. reported a case of squamous cell carcinoma misdiagnosed as a denturerelated traumatic ulcer [6]. Meanwhile, de Sant' Ana dos Santos et al. reported misdiagnosis of lip SCC as actinic cheilitis [7]. A case of gingival SCC masquerading as an aphthous ulcer was also reported by Kumari et al. [8]. This time elapse might jeopardize patients' overall prognosis; therefore, attempts should be done to come to timely diagnosis via more logical routes such as decision trees rather than test-anderror methods. A decision tree is a flowchart that organizes features of lesions so that the clinician can make a series of orderly decisions to reach a logical conclusion. To use the decision tree, the clinician begins from the left side of the tree, makes the first decision, and proceeds to the far right of the tree, where the names of entities are listed $[9,10]$. This narrative review article aims to introduce an updated decision 


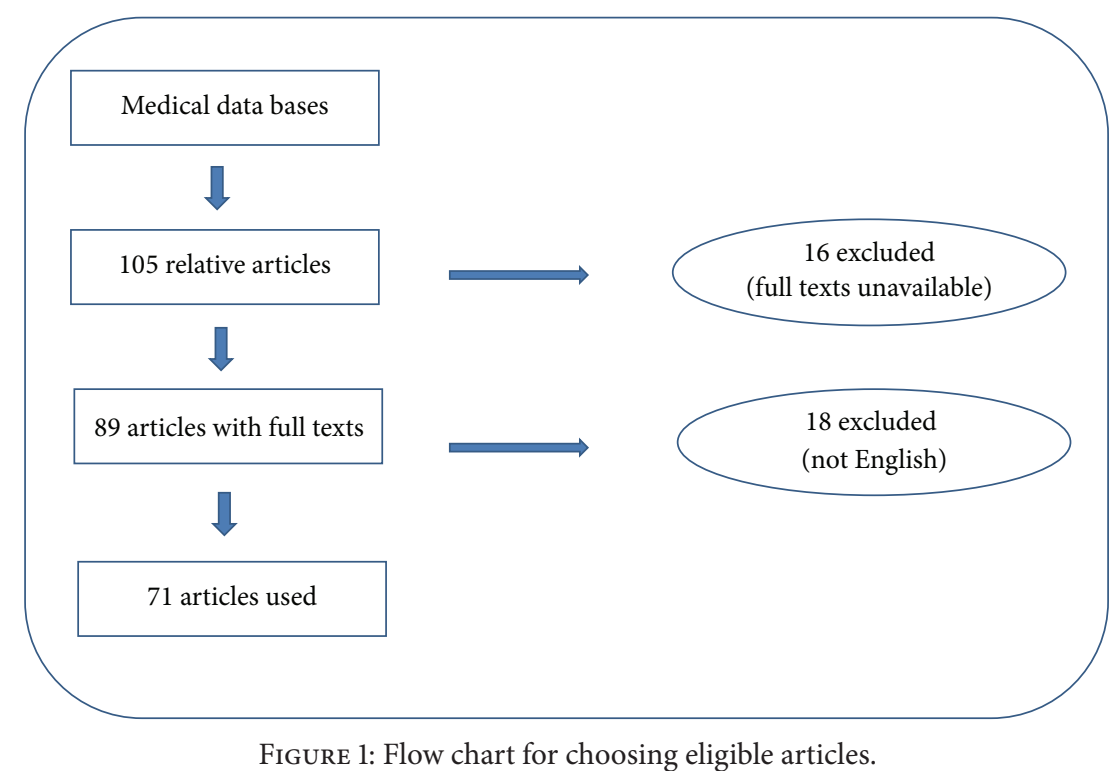

tree for diagnosing oral ulcerative lesions on the basis of their diagnostic features.

\section{Search Strategy}

General search engines and specialized databases including PubMed, PubMed Central, Medline Plus, EBSCO, Science Direct, Scopus, Embase, and authenticated textbooks were used by the first author and the corresponding author to find relevant topics by means of MeSH keywords such as "oral ulcer," "stomatitis," and "mouth diseases." Related English-language articles published since 1983 to 2015 in both medical and dental journals including reviews, metaanalyses, original papers (randomized or nonrandomized clinical trials, prospective or retrospective cohort studies), case reports, and case series on oral ulcers, stomatitis, and oral disease were appraised.

\section{Results}

Out of a total of 105 relative articles, 34 were excluded due to lack of full texts or being written in languages other than English. Finally, 4 textbooks and 71 papers were selected including 32 reviews, 27 case reports or case series, and 12 original articles (Figure 1).

In this narrative review article, oral ulcerative lesions were categorized into three major groups: acute, chronic, and recurrent ulcers (Tables 1-3) and into five subgroups: solitary acute, multiple acute, solitary chronic, multiple chronic, and solitary/multiple recurrent, based on the number and duration of lesions. In total, 29 entities were organized in the form of a decision tree (Figure 2) in order to help clinicians establish a logical diagnosis by stepwise progression. The first decision to be made is whether the ulcerative lesion is of an acute, chronic, or recurrent nature; thereafter, the lesion(s) should be placed in one of the five subgroups. Then, the clinician can consult the list of diagnoses in the relevant category.

\subsection{Clinical Features of Oral Ulcerative Lesions}

\subsubsection{Acute Solitary Ulcers}

Traumatic Ulcer. Traumatic injuries of the oral mucosa are quite common. They are caused by mechanical damage (contact with sharp foodstuff; accidental biting during mastication, talking, or even sleeping) and thermal, electrical, or chemical burns [11]. Traumatic ulcers are most common on the tongue, lips, and buccal mucosa [5]. According to Chen et al., traumatic lesions of the oral cavity were mostly seen on the buccal mucosa (42\%), followed by the tongue $(25 \%)$ and the lower lip (9\%) [12]. Noteworthy, traumatic ulcers are more common in men than women (male: female ratio of $2.7: 1$ ) [12]. These lesions may persist for a few days or even several weeks, especially in the case of tongue ulcers due to repeated insults to the tissues $[5,33]$. The borders of traumatic ulcers are usually slightly raised and reddish, with a yellowish-white necrotic pseudomembrane that can be readily wiped off (Figure 3 ). Ulcers on the lip vermilion usually have a crusted surface [5]. Traumatic ulcers normally become painless within three days after the injury had been eliminated and, in most cases, heal within 10 days [5].

Necrotizing Sialometaplasia. Necrotizing sialometaplasia (NS) is a self-limiting, benign, inflammatory disease of the salivary glands more frequently seen in middle-aged men. Although the main etiology is not clear; many authors believe that local infarction due to ischemia of the salivary tissue is the causative factor. Meanwhile, a number of potential predisposing factors have been suggested such as sharp direct local trauma (local anesthesia, intubation, and surgical procedures), use of ill-fitting dentures, violent or provoked vomiting (in patients with bulimia), upper respiratory infection, and radiotherapy [11, 34]. NS appears as a craterlike ulcer with indurated and well-delineated borders [34]. More than $75 \%$ of all cases occur on the posterior part of the palate, followed by the lower lip, retromolar pad, sublingual 
TABLE 1: Clinical characteristics of acute oral ulceration [2, 3, 11-20].

\begin{tabular}{|c|c|c|c|c|c|c|}
\hline Lesion & $\begin{array}{l}\text { Gender } \\
\text { predominance }\end{array}$ & $\begin{array}{l}\text { Age } \\
\text { predilection }\end{array}$ & Location & Shape of ulcer & $\begin{array}{l}\text { Number } \\
\text { of ulcers }\end{array}$ & Distinguishing features \\
\hline Traumatic ulcer & Men & $\mathrm{NA}^{*}$ & $\begin{array}{l}\text { Tongue, lip, } \\
\text { buccal } \\
\text { mucosa }\end{array}$ & Symmetrical/asymmetrical & Solitary & $\begin{array}{l}\text { Slightly raised and reddish } \\
\text { borders, necrotic } \\
\text { pseudomembrane, which } \\
\text { heals within } 10 \text { days }\end{array}$ \\
\hline $\begin{array}{l}\text { Necrotizing } \\
\text { sialometaplasia }\end{array}$ & Men & Middle age & $\begin{array}{l}\text { Posterior } \\
\text { palate, lower } \\
\text { lip, } \\
\text { retromolar } \\
\text { pad }\end{array}$ & Crater-like & Solitary & $\begin{array}{l}\text { Ulcers with indurated } \\
\text { borders, self-limiting after } 5 \\
\text { to } 7 \text { weeks }\end{array}$ \\
\hline $\begin{array}{l}\text { Primary herpetic } \\
\text { gingivostomatitis }\end{array}$ & NA & $2-3$ years & $\begin{array}{l}\text { Keratinized } \\
\text { and nonkera- } \\
\text { tinized } \\
\text { mucosa }\end{array}$ & $\begin{array}{l}\text { Ulcers with scalloped } \\
\text { borders and erythematous } \\
\text { halo }\end{array}$ & Multiple & $\begin{array}{l}\text { Prodromal fever, nausea, } \\
\text { anorexia, and irritability } \\
\text { generalized gingivitis, } \\
\text { painful ulcers covered by a } \\
\text { yellowish pseudomembrane, } \\
\text { submandibular } \\
\text { lymphadenitis, halitosis, and } \\
\text { dysphagia, self-limiting after } \\
5 \text { to } 7 \text { days }\end{array}$ \\
\hline $\begin{array}{l}\text { Herpes zoster infection } \\
\text { (shingles) }\end{array}$ & $\mathrm{NA}$ & $\begin{array}{l}>50 \text { years of } \\
\text { age }\end{array}$ & $\begin{array}{l}\text { Hard palate, } \\
\text { gingivae, } \\
\text { tongue }\end{array}$ & $\begin{array}{l}\text { Ulcers with scalloped } \\
\text { borders, Zosteriform } \\
\text { pattern }\end{array}$ & Multiple & $\begin{array}{l}\text { Prodromal unilateral pain, } \\
\text { clustered small ulcers with } \\
\text { characteristic unilateral } \\
\text { pattern, self-limiting, healing } \\
\text { within } 10-14 \text { days }\end{array}$ \\
\hline Herpangina & NA & $\begin{array}{l}<10 \text { years of } \\
\text { age }\end{array}$ & $\begin{array}{l}\text { Oropharynx, } \\
\text { soft palate, } \\
\text { tonsillar } \\
\text { pillars }\end{array}$ & Small ulcers & Multiple & $\begin{array}{l}\text { Vesicular exanthema and } \\
\text { ulcers }\end{array}$ \\
\hline $\begin{array}{l}\text { Hand-foot-and-mouth } \\
\text { disease }\end{array}$ & NA & $\begin{array}{l}<10 \text { years of } \\
\text { age }\end{array}$ & $\begin{array}{l}\text { Tongue, hard, } \\
\text { and soft } \\
\text { palate, buccal } \\
\text { mucosa }\end{array}$ & Small ulcers & Multiple & $\begin{array}{l}\text { Oral ulcers along with skin } \\
\text { rash on the hands and feet }\end{array}$ \\
\hline Erythema multiforme & men & $20-40$ years & $\begin{array}{l}\text { Lips, buccal } \\
\text { mucosa, } \\
\text { tongue }\end{array}$ & Large and confluent & Multiple & $\begin{array}{l}\text { Prodromal skin target } \\
\text { lesions, bullae and } \\
\text { ulcerations with irregular } \\
\text { borders and inflammatory } \\
\text { halo, bloody encrustations } \\
\text { on the lips }\end{array}$ \\
\hline $\begin{array}{l}\text { Necrotizing ulcerative } \\
\text { gingivitis }\end{array}$ & NA & $\begin{array}{l}\text { Young adults } \\
\text { (18-20 years } \\
\text { of age) }\end{array}$ & $\begin{array}{l}\text { Papillary and } \\
\text { marginal } \\
\text { gingivae }\end{array}$ & Crater like & Multiple & $\begin{array}{l}\text { Sore gums, bleeding gums, } \\
\text { ulceration, and necrosis of } \\
\text { the interdental papillae, fetid } \\
\text { odor, fever, and malaise }\end{array}$ \\
\hline $\begin{array}{l}\text { Oral hypersensitivity } \\
\text { reactions }\end{array}$ & NA & NA & $\begin{array}{l}\text { Any site } \\
\text { intraorally }\end{array}$ & $\begin{array}{l}\text { Several clinical } \\
\text { manifestations }\end{array}$ & Multiple & $\begin{array}{l}\text { Lichenoid reactions, fixed } \\
\text { drug eruption, swelling of } \\
\text { the lips, and oral allergy } \\
\text { syndrome }\end{array}$ \\
\hline Plasma cell stomatitis & NA & NA & $\begin{array}{l}\text { Gingivae, } \\
\text { sulcus, buccal } \\
\text { mucosa }\end{array}$ & Desquamative gingivitis & Multiple & $\begin{array}{l}\text { Ulceration, epithelial } \\
\text { sloughing, and } \\
\text { desquamation, angular } \\
\text { cheilitis, atrophic fissured } \\
\text { lips, self-limiting }\end{array}$ \\
\hline $\begin{array}{l}\text { Chemotherapy-related } \\
\text { ulcers }\end{array}$ & NA & NA & $\begin{array}{l}\text { Any site } \\
\text { intraorally }\end{array}$ & Asymmetrical ulcers & Multiple & $\begin{array}{l}\text { Erythema and ulceration } 5 \text { to } \\
7 \text { days after onset of } \\
\text { chemotherapy, } \\
\text { spontaneously resolution } \\
\text { after completion of } \\
\text { chemotherapy }\end{array}$ \\
\hline
\end{tabular}

\footnotetext{
${ }^{*}$ NA: not assigned.
} 
TABLE 2: Clinical characteristics of chronic oral ulceration [1-4, 11, 20-28].

\begin{tabular}{|c|c|c|c|c|c|c|}
\hline Lesion & $\begin{array}{l}\text { Gender } \\
\text { predominance }\end{array}$ & $\begin{array}{l}\text { Age } \\
\text { predilection }\end{array}$ & Location & Shape of ulcer & $\begin{array}{l}\text { Number } \\
\text { of ulcers }\end{array}$ & Distinguishing features \\
\hline $\begin{array}{l}\text { Sustained traumatic } \\
\text { ulcer }\end{array}$ & $\mathrm{NA}^{*}$ & NA & $\begin{array}{l}\text { Tongue, lips, } \\
\text { buccal mucosa }\end{array}$ & Symmetrical/asymmetrical & Solitary & $\begin{array}{l}\text { Central removable, yellow } \\
\text { fibrinopurulent membrane; a } \\
\text { raised, rolled border of } \\
\text { hyperkeratosis immediately } \\
\text { adjacent to the area of } \\
\text { ulceration }\end{array}$ \\
\hline $\begin{array}{l}\text { Necrotizing } \\
\text { sialometaplasia }\end{array}$ & Men & $\begin{array}{l}\text { Average } \\
\text { age: } 46 \\
\text { years }\end{array}$ & $\begin{array}{l}\text { Palate, retromolar } \\
\text { pad, lips }\end{array}$ & Craterlike & Solitary & $\begin{array}{l}\text { Deep ulcer with a yellowish } \\
\text { base, self-limiting, healing } \\
\text { time between } 2 \text { and } 12 \text { weeks }\end{array}$ \\
\hline Eosinophilic ulcer & Women & $40-60$ years & $\begin{array}{l}\text { Tongue, buccal } \\
\text { mucosa }\end{array}$ & Punched out & Solitary & $\begin{array}{l}\text { Slow-healing ulcer with a } \\
\text { rolled border, surrounding } \\
\text { erythema or keratosis, mostly } \\
\text { asymptomatic, healing time } \\
\text { between } 1 \text { week and } 1 \text { year } \\
\end{array}$ \\
\hline $\begin{array}{l}\text { Ulcerative squamous } \\
\text { cell carcinoma }\end{array}$ & Men & $>40$ years & $\begin{array}{l}\text { Lower lip, floor of } \\
\text { the mouth, tongue }\end{array}$ & Craterlike & Solitary & $\begin{array}{l}\text { Rolled, indurated borders } \\
\text { and a velvety base }\end{array}$ \\
\hline $\begin{array}{l}\text { Cytomegalovirus- } \\
\text { associated } \\
\text { ulceration }\end{array}$ & NA & NA & $\begin{array}{l}\text { Keratinized and } \\
\text { nonkeratinized } \\
\text { mucosa }\end{array}$ & Large ulcer & $\begin{array}{l}\text { Solitary, } \\
\text { rarely } \\
\text { multiple }\end{array}$ & $\begin{array}{l}\text { Painful, necrotic, with } \\
\text { minimally rolled border, } \\
\text { mostly in } \\
\text { immunocompromised } \\
\text { patients }\end{array}$ \\
\hline Tuberculous ulcer & Men & NA & $\begin{array}{l}\text { Tongue, gingivae, } \\
\text { floor of the mouth }\end{array}$ & Undermined borders & Solitary & $\begin{array}{l}\text { May be ragged and } \\
\text { indurated, often painful }\end{array}$ \\
\hline $\begin{array}{l}\text { Syphilitic ulceration } \\
\text { (chancre) }\end{array}$ & NA & NA & $\begin{array}{l}\text { Lips, tongue, } \\
\text { palate }\end{array}$ & Clean-based ulceration & Solitary & $\begin{array}{l}\text { Red purple or brown base, } \\
\text { ragged rolled border, cervical } \\
\text { lymphadenopathy }\end{array}$ \\
\hline Oral blastomycosis & Men & NA & $\begin{array}{l}\text { Any oral mucosal } \\
\text { surface }\end{array}$ & Nonspecific ulcer & Solitary & $\begin{array}{l}\text { Painless, irregular rolled } \\
\text { borders and verrucous } \\
\text { mucosal hyperplasia, painful, } \\
\text { concomitant pulmonary } \\
\text { lesions on chest radiographs }\end{array}$ \\
\hline Oral mucormycosis & NA & NA & Palate & Verrucous ulcer & Solitary & $\begin{array}{l}\text { Large deep necrotic ulcer, } \\
\text { associated with concomitant } \\
\text { pulmonary disease and an } \\
\text { underlying debilitating } \\
\text { disease }\end{array}$ \\
\hline Pemphigus vulgaris & NA & NA & $\begin{array}{l}\text { Buccal mucosa, } \\
\text { palate, gingivae }\end{array}$ & Map-like & Multiple & $\begin{array}{l}\text { Shallow irregular ulcers with } \\
\text { peripheral extension, positive } \\
\text { Nikolsky sign, desquamative } \\
\text { gingivitis }\end{array}$ \\
\hline $\begin{array}{l}\text { Mucous membrane } \\
\text { pemphigoid }\end{array}$ & Women & $>50$ years & $\begin{array}{l}\text { Gingivae, buccal } \\
\text { mucosa, palate }\end{array}$ & $\begin{array}{l}\text { Nonspecific-appearing } \\
\text { erythema and erosions }\end{array}$ & Multiple & $\begin{array}{l}\text { Desquamative gingivitis as } \\
\text { the most common oral } \\
\text { presentation, blood blisters, } \\
\text { skin lesions in } 30-40 \% \text { of } \\
\text { cases }\end{array}$ \\
\hline Bullous pemphigoid & NA & $\begin{array}{l}>60 \text { years of } \\
\text { age }\end{array}$ & Gingivae & Discrete vesicle formation & Multiple & $\begin{array}{l}\text { Desquamative gingivitis as } \\
\text { the most frequent oral } \\
\text { manifestation, self-limiting, } \\
\text { early remission }\end{array}$ \\
\hline Lichen planus & Women & Middle age & $\begin{array}{l}\text { Buccal mucosa, } \\
\text { tongue, gingivae }\end{array}$ & & Multiple & $\begin{array}{l}\text { Accompanying reticular or } \\
\text { papular lesions, } \\
\text { desquamative gingivitis, } \\
\text { painful }\end{array}$ \\
\hline Linear IgA disease & Women & $\begin{array}{l}\text { 6th and } 7 \text { th } \\
\text { decades of } \\
\text { life }\end{array}$ & $\begin{array}{l}\text { Hard and soft } \\
\text { palate, tonsillar } \\
\text { pillars, buccal } \\
\text { mucosa }\end{array}$ & $\begin{array}{l}\text { Clinically } \\
\text { indistinguishable from the } \\
\text { oral lesions of MMP }\end{array}$ & Multiple & $\begin{array}{l}\text { Vesicles, painful ulcerations } \\
\text { or erosions, desquamative } \\
\text { gingivitis/cheilitis }\end{array}$ \\
\hline
\end{tabular}

${ }^{*}$ NA: not assigned. 
TABLE 3: Clinical characteristics of recurrent oral ulceration [2-4, 11, 20, 29-32].

\begin{tabular}{|c|c|c|c|c|c|c|}
\hline Lesion & $\begin{array}{l}\text { Gender } \\
\text { predominance }\end{array}$ & $\begin{array}{l}\text { Age } \\
\text { predilection }\end{array}$ & Location & Shape of ulcer & $\begin{array}{l}\text { Number of } \\
\text { ulcers }\end{array}$ & Distinguishing features \\
\hline $\begin{array}{l}\text { Recurrent aphthous } \\
\text { stomatitis }\end{array}$ & Women & $\begin{array}{l}\text { Beginning } \\
\text { at 2nd } \\
\text { decade }\end{array}$ & $\begin{array}{l}\text { Nonkeratinized } \\
\text { mucosa in healthy } \\
\text { patients }\end{array}$ & Symmetrical & Solitary/multiple & $\begin{array}{l}\text { Prodromal burning, painful, } \\
\text { round fibrin covered with } \\
\text { erythematous borders, } 3 \text { clinica } \\
\text { types: minor, major, } \\
\text { herpetiform, self-limiting }\end{array}$ \\
\hline $\begin{array}{l}\text { Recurrent herpetic } \\
\text { stomatitis }\end{array}$ & $\mathrm{NA}^{*}$ & NA & $\begin{array}{l}\text { Keratinized } \\
\text { mucosa especially } \\
\text { hard palate in } \\
\text { healthy patients }\end{array}$ & $\begin{array}{l}\text { Scalloped } \\
\text { borders }\end{array}$ & Multiple & $\begin{array}{l}\text { Two subgroups: recurrent } \\
\text { herpes simplex labialis, } \\
\text { recurrent intraoral herpes, } \\
\text { unilateral }\end{array}$ \\
\hline $\begin{array}{l}\text { Herpes-associated } \\
\text { erythema multiform }\end{array}$ & Men & $20-40$ years & Lips & Map-like & Multiple & $\begin{array}{l}\text { Bullae and ulcerations with } \\
\text { irregular borders and } \\
\text { inflammatory halo, bloody } \\
\text { encrustations on the lips }\end{array}$ \\
\hline Cyclic neutropenia & NA & $\begin{array}{l}\text { Begins in } \\
\text { childhood }\end{array}$ & $\begin{array}{l}\text { Any oral mucosa } \\
\text { exposed to trauma }\end{array}$ & Aphthous-like & Multiple & $\begin{array}{l}\text { Episodic ulcers with } \\
\text { erythematous halo, } \\
\text { concomitant fever, } \\
\text { periodontitis, marked gingival } \\
\text { recession, and systemic } \\
\text { infections }\end{array}$ \\
\hline Behçet's disease & $\begin{array}{l}\text { Balanced } \\
\text { male/female } \\
\text { ratio }\end{array}$ & $\begin{array}{l}\text { Between } \\
\text { the ages of } \\
25 \text { and } 40\end{array}$ & $\begin{array}{l}\text { Anywhere on the } \\
\text { oral or pharyngeal } \\
\text { mucosa }\end{array}$ & Aphthous-like & Multiple & $\begin{array}{l}\text { Concomitant genital ulcers, } \\
\text { ocular inflammation, and skin } \\
\text { lesions }\end{array}$ \\
\hline
\end{tabular}

*NA: not assigned.

region, tongue, and larynx [11, 34]. The size of the lesion ranges from less than $1 \mathrm{~cm}$ to over $5 \mathrm{~cm}$ [11]. The healing time of NS varies as well. Chen et al. showed a considerable improvement in healing process after 10 days [12]. However, complete healing is usually observed only after five to seven weeks $[11,34]$.

\subsubsection{Acute Multiple Ulcers}

Primary Herpetic Gingivostomatitis. Primary herpetic gingivostomatitis is the most common pattern of symptomatic herpes simplex virus (HSV) infection. Over $90 \%$ of cases are caused by HSV type 1 , and the remainder are caused by HSV2 [12]. It can be asymptomatic or very mild in young patients but is associated with more severe general symptoms in the elderly [1]. Most cases occur between the ages of six months and 5 years, with peak prevalence between 2 and 3 years [11]. Fever, nausea, anorexia, and irritability are initial symptoms. Oral manifestations consist of a generalized gingivitis followed, after 2-3 days, by pin-headed vesicles that readily rupture and give rise to painful ulcers covered by a yellowish pseudomembrane. They often coalesce into larger ulcers. Keratinized and nonkeratinized mucosa can be affected, and the number of the lesions is quite variable [13]. In many cases, punched-out erosions along the free gingival margin have been reported [11]. Submandibular lymphadenitis, halitosis, and difficulty in swallowing are noted in most cases $[13,35]$. Noteworthy, some adult patients may present with pharyngotonsillitis. In addition, involvement of the oral mucosa anterior to Waldeyer's ring is encountered in roughly $10 \%$ of patients [11]. The ulcers usually heal spontaneously after 5 to 7 days, with no scarring, but may persist for two weeks in severe cases $[13,35,36]$.

Herpes Zoster Infection (Shingles). Herpes zoster infection (HZI) is a less common viral infection brought about by the reactivation of Varicella Zoster Virus (VZV) [14, 37, 38], which may happen spontaneously or as a result of immune system deficiency. Increased age, trauma (from dental procedures), psychological stress, malignancy, radiotherapy, and immunocompromised conditions such as organ transplantation, immunosuppressive therapy, and HIV infection are contributory factors for VZV reactivation. The incidence of HZI is $1.5-3$ cases per 1,000 persons, which increases to 10 per 1,000 in people over 75 years of age $[15,37]$. Majority of HZI involve the thoracic and lumbar dermatomes, but nearly $13 \%$ of patients present with involvement of the trigeminal nerve branch, most commonly the ophthalmic branch. The condition is acutely painful and patients with involvement of the maxillary branch experience a prodromal phase of unilateral pain, burning, and tenderness, usually on the palate (Figure 4). After several days, painful, clustered ulcers of $1-5 \mathrm{~mm}$ in diameter appear on the hard palate or buccal gingivae in a characteristic unilateral pattern. The ulcers tend to heal within 10-14 days. Development of blisters and ulcers on the mandibular gingivae and tongue is indicative of mandibular branch involvement. This entity is self-limiting, and management of oral lesions is directed toward pain control, supportive care, and hydration. Use of acyclovir, valacyclovir, or famciclovir is also effective in treating HZI when started within 72 hours of disease onset $[3,13]$. 


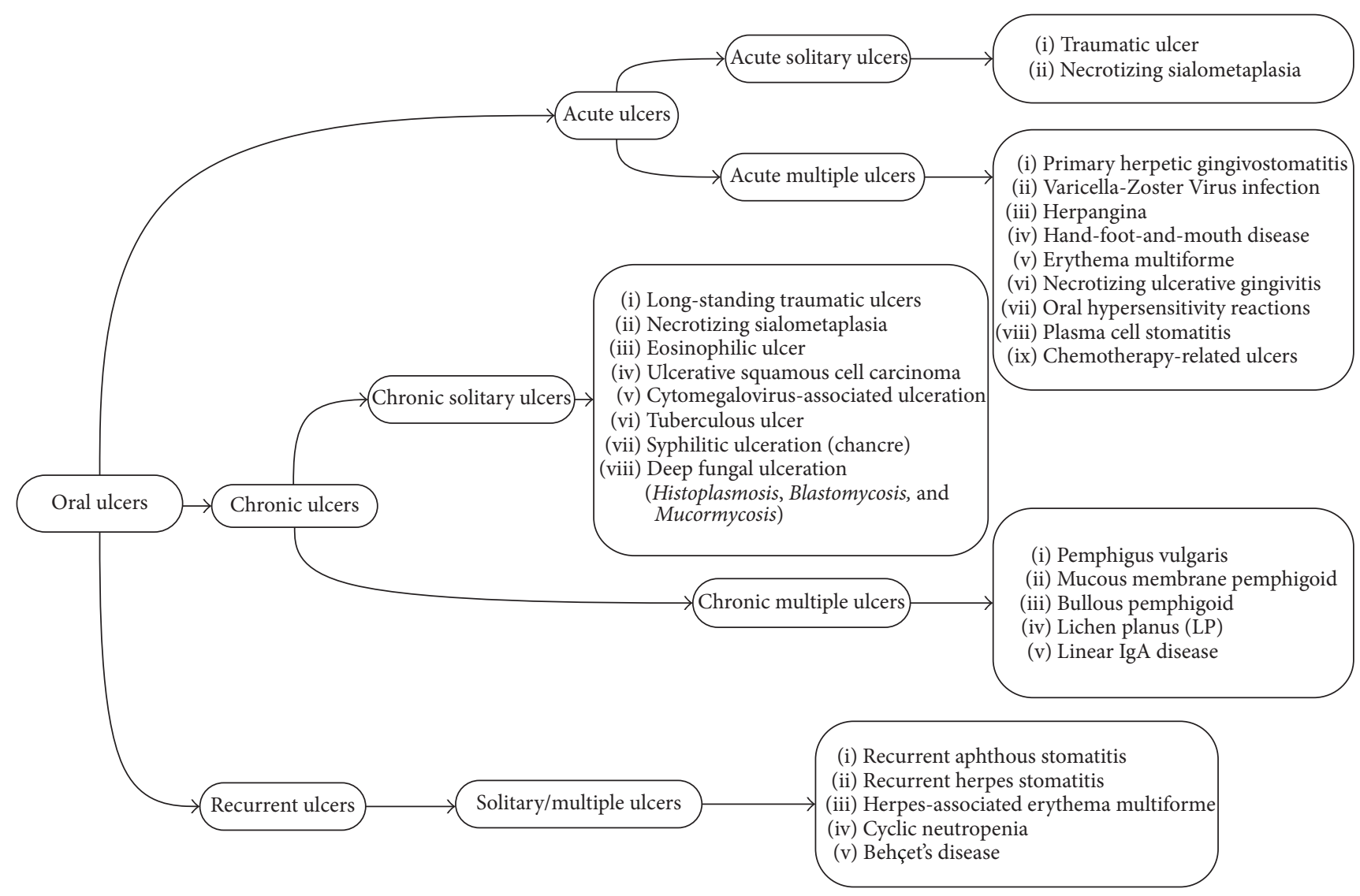

FIGURE 2: Decision tree of oral ulcerative lesions.

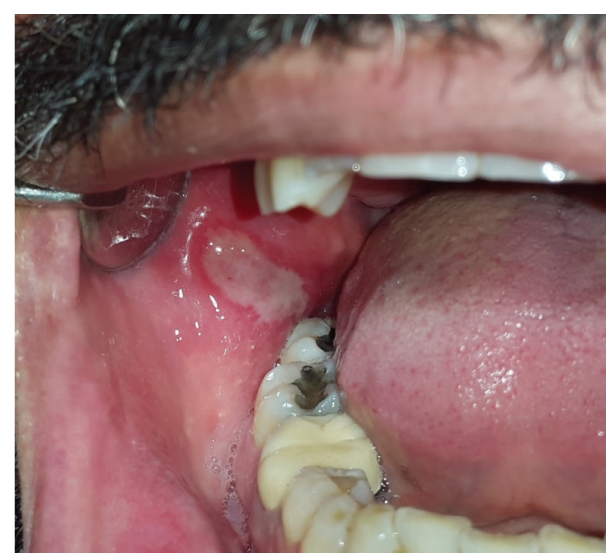

Figure 3: Traumatic ulcer coated with pseudomembrane and surrounded by inflammatory halo.

Herpangina. Herpangina presents as multiple vesicular exanthema and ulcers of the oropharynx, soft palate, and tonsillar pillars [16, 17] (Figure 5). Children under 10 years of age are usually affected, and outbreaks occur in epidemics in summer. Coxsackie virus A genotypes 1-10 (CAV1-10), A12, $\mathrm{A} 16$, and $\mathrm{A} 22$ and Coxsackie virus B genotypes (CBV2-5) and Echo virus 18 and Entero virus 71 identified as etiologic factors [16]. It is a self-limiting disease and management directed

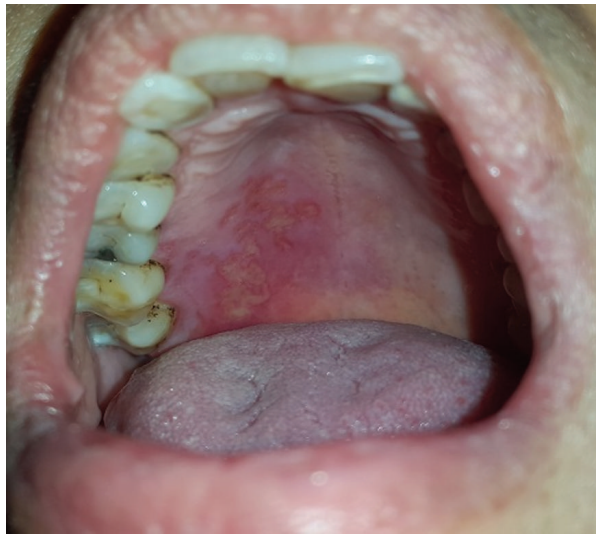

FIGURE 4: Herpes zoster presenting as small and coalesced ulcers with scalloped borders, unilateral and zosteriform pattern.

toward control of oral pain and fever. Effective antiviral medications for Coxsackie virus infections are not available yet [17].

Hand-Foot-and-Mouth Disease. Hand-foot-and-mouth disease (HFM) is one of the common causes of morbidity among children below 10 years of age [16, 39]. All of the patients have skin rash, especially on the hands and feet and $30 \%$ on the 


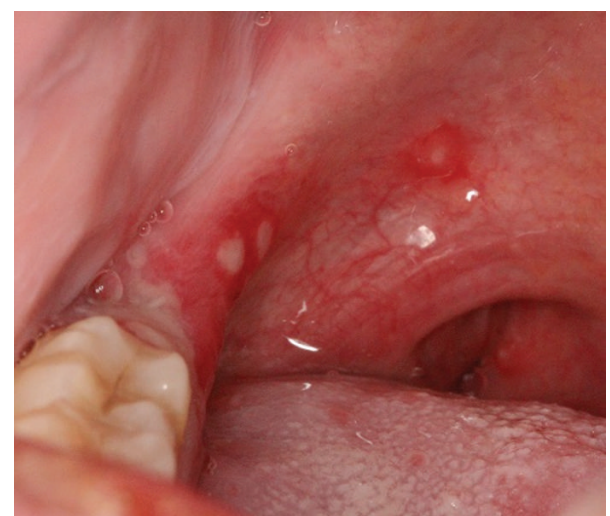

FIGURE 5: Small and symmetrical ulcers of herpangina on the soft palate and retromolar pad.

buttocks. Oral ulcers are usually located on the tongue, hard and soft palate, and buccal mucosa. Management is similar to herpangina [3].

Erythema Multiforme. Erythema multiforme (EM) is a mucocutaneous hypersensitivity reaction with different etiologies. It is characterized by irregular red macules, papules, and vesicles that coalesce with each other to grow larger and make plaques on the skin called target lesions [40]. Oral lesions usually appear as erythematous macules on the lips and buccal mucosa, followed by bullae and ulcerations with irregular borders and inflammatory halo. Bloody encrustations can be observed on the lips, which is a diagnostic feature $[18,41]$. EM can be triggered by medications such as sulfonamide, penicillin, cephalosporins, quinolones, analgesics, and nonsteroidal anti-inflammatory drugs (NSAIDs) or several infections (herpes simplex virus, Epstein-barr Virus, Cytomegalovirus, Varicella Zoster Virus, fungal agents, and parasites) [40]. EM typically affects young adults (20-40 years) and teenagers, but the onset might be as late as 50 years of age or elder [41]. There is a male predilection with male to female ratio of $3: 2$ [42]. According to recent evidence, EM has been categorized as minor, major, Steven-Johnson Syndrome or Toxic Epidermal Necrolysis. The former is the mildest type and the latter is the most severe one [40]. Prodromal signs such as fever, lymphadenopathy, headache, malaise, cough, and sore throat may be noticed one week prior to onset of mucocutaneous erythema or blisters [18, $40,41]$. Treatment mainly depends on the severity of clinical presentations. In the mild forms, healing takes place within 10 to 20 days; therefore, patients only need local wound care, liquid diet, and topical analgesics or anesthetics for pain control $[40,41]$.

Necrotizing Ulcerative Gingivitis. Necrotizing ulcerative gingivitis (NUG) is an acute infectious disease of the gingivae. It is characterized by "punched-out" ulcerations, and necrosis on the papillary and marginal gingivae (Figure 6) as well as severe gingival pain and bleeding $[19,43]$. There are some predisposing factors such as smoking, poor oral hygiene, preexisting gingivitis, malnutrition, psychological stress, and

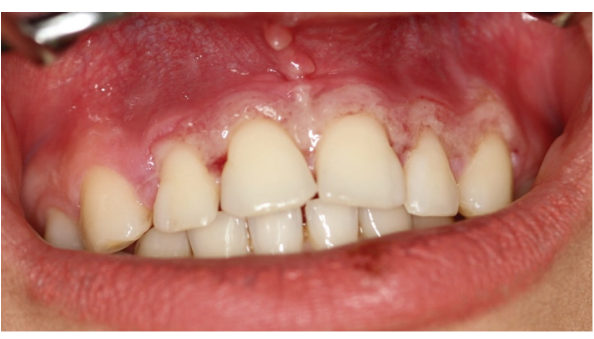

Figure 6: Punched-out necrotic ulcers of NUG on the gingival papillae.

HIV infection. The above-mentioned factors usually lead to immunodysregulation including depressed polymorphonuclear leukocytes, antibody response, and lymphocyte mitogenesis [43]. NUG usually affects young adults (18-20 years of age), and it is estimated to be seen in $0.5 \%$ to $11 \%$ of the population $[19,43]$. The diagnosis of NUG is based on three essential symptoms: sore gums, bleeding gums, and, the most diagnostic criterion, ulceration and necrosis of the interdental papillae [19]. Treatment is based on mechanical removal of tartar with local (chlorhexidine, $0.12 \%$ twice daily) and systemic (amoxicillin $250 \mathrm{mg}$ and metronidazole $250 \mathrm{mg}$, three times a day for 7 days) delivery of antimicrobial agents. Adequate treatment usually prevents progression of the lesions. Healing is expected in a few days, whereas inadequate treatment can lead to deterioration of lesions in the form of necrotizing ulcerative periodontitis (NUP) $[19,43]$.

Oral Hypersensitivity Reactions. Oral hypersensitivity reactions (OHRs) have a variety of manifestations: acute onset of EM ulcers, red and white reticular lesions such as lichenoid reactions, fixed drug eruption (usually seen as ulcers on the lip vermilion after exposure to drugs with resolution on withdrawal and relapse on rechallenge), swelling of the lips, and oral allergy syndrome (itching with or without swelling of oral structures and oropharynx) [3, 44, 45].

Plasma Cell Stomatitis. Plasma cell stomatitis (PCS) was first described in the late 1960s and early 1970s as a hypersensitivity reaction and likely a contact stomatitis to a component of chewing gum. This entity usually occurs few days after exposure and presents as erythematous macular areas of oral cavity. Ulceration, epithelial sloughing, and desquamation may also be seen. Gingivae is the mostly affected site. Angular cheilitis with fissuring and dry atrophic lips have been found in patients with PCS [3]. OHRs and PCS are usually selflimiting. Nevertheless, pain control and anti-inflammatory agents can help diminish the healing time [3, 44, 45].

Chemotherapy-Related Ulcers. Chemotherapeutic agents may cause ulcers through direct or indirect mechanisms. Bone marrow suppression and immune response of oral mucosa, which leads to bacterial, fungal, or viral infections, happen during indirect effect of chemotherapeutic agents. Other medications cause oral ulcerative lesions via direct impact on replication and growth of the oral epithelial cells $[3,46]$. 
Kolbinson et al. demonstrated that early changes in the oral mucosa such as erythema and ulceration appear between 5 and 7 days after onset of chemotherapy [47]. It is also noted that these lesions are considered as risk factors for systemic infections [48]. Moreover, Dreizen et al. pointed out that $30 \%$ to $50 \%$ of patients undergoing chemotherapy develop oral lesions [49]. After completion of chemotherapy, the lesions resolve spontaneously; however, anti-inflammatory drugs may be useful in minimizing chemotherapy-related ulcers $[3,46]$.

\subsubsection{Chronic Solitary Ulcers}

Sustained Traumatic Ulcers. Chronic injuries of oral mucosa may lead to solitary long standing ulcerative lesions; therefore, traumatic ulcer can also be classified as a chronic solitary ulcer. This entity has been reported by Pattison as a self-inflicted gingival lesion in patients who were seeking prescriptions for narcotic drugs [50]. Chronic traumatic ulcerations usually occur on the tongue, lips, and buccal mucosa [11] as ulcerative areas surrounding a central removable, yellow fibrinopurulent membrane. In many cases, the lesion develops a raised, rolled border of hyperkeratosis immediately adjacent to the area of ulceration [11, 51, 52]. Most traumatic ulcers become painless and heal within 10 days. However, some lesions persist for several weeks because of continued traumatic insults, irritation by the oral liquids, or secondary infection. There are different treatment modalities, but coating the ulcerated surface with fluocinonide or triamcinolone acetonide in an emollient base after meals and before bed time usually relieves pain and decreases duration of healing [5].

Necrotizing Sialometaplasia. Although this lesion usually occurs on the palate, it can be seen anywhere from oral mucosa, which contains salivary glands including the retromolar trigon and the lips. NS initially presents as a tender erythematous nodule, followed by a deep ulcer with a yellowish base [3]. Average age of patients is 46 years and it is more common in males. It resembles squamous cell carcinoma and ulcerated mucoepidermoid carcinoma to a large extent during its ulcerated phase [5]. NS is mainly a self-limiting lesion, and healing time may be varied from 2 to 12 weeks according to the severity of the lesion $[5,11,34]$. Therefore, NS can be classified as an acute or chronic solitary ulcer.

Eosinophilic Ulcer. Eosinophilic ulcer (EU) or traumatic ulcerative granuloma with stromal eosinophilia (TUGSE) is a chronic solitary ulcer of oral mucosa, which is most frequently seen in patients aged $40-60$ years [21], but occurs in young and elderly patients as well [53]. Male to female ratio is $1: 1$, or slightly more prevalent in women [53]. The most frequently affected site is the tongue (about $60 \%$ of cases), followed by buccal mucosa, retromolar region, floor of the mouth, and lips $[3,21]$. Eosinophilic ulcer manifests as a slowhealing ulcer with a rolled or elevated border mimicking a squamous cell carcinoma (Figure 7). They ranged from 0.5 to several $\mathrm{cm}$ in size. In two-thirds of cases, the lesion may be asymptomatic and persists for months. The main etiology is not clear, but trauma has been elicited in $20 \%$ to $50 \%$ of cases

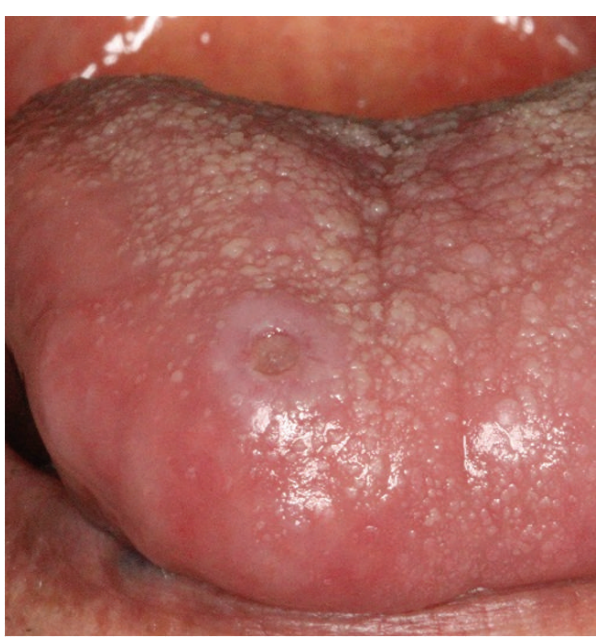

FIgURe 7: Punched-out eosinophilic ulcer on dorsal surface of the tongue with a raised keratotic border.

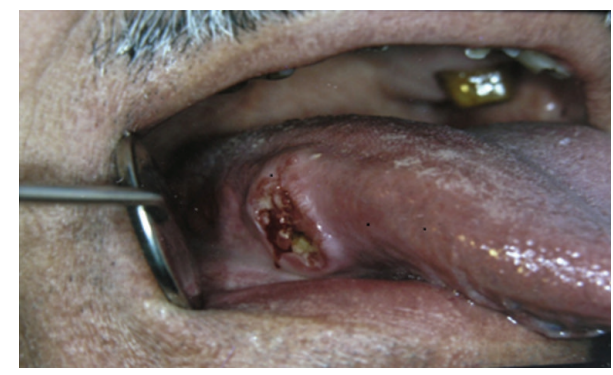

FIGURE 8: Ulcerative SCC of the tongue with rolled borders.

[21]. The duration of healing time ranges from 1 week to 1 year [21]. Surgical excision is the accepted treatment method, and recurrence is rare. In addition, intralesional corticosteroids, oral corticosteroids, topical antibiotics, and cryotherapy have been also suggested [53].

Ulcerative Squamous Cell Carcinoma. Squamous cell carcinoma (SCC) represents about $95 \%$ of all oral malignancies $[22,54]$. It presents as a red, white, red-white, exophytic, or ulcerative lesion. SCC is a persistent ulcer in the oral cavity, which is of high importance especially on the lips. SCC is often asymptomatic; therefore, patients usually are not aware of it until it has become relatively progressive. The classic ulcerative SCC is described as a craterlike lesion having a rolled, indurated border and a velvety base (Figure 8). It may be covered with a crust when occurring on the vermilion $[5,22]$. The mostly affected sites in the oral cavity are lower lip, floor of the mouth, and ventral and lateral borders of the tongue. Lesions are usually solitary, but in rare cases multifocal [5]. According to Wood and Goaz, a lesion is most likely a SCC if the patient is male, older than 40 years, smokes or drinks heavily, no evidence of trauma or systemic disease exists, serologic findings are negative, and the lesion is not located on the posterolateral region of the hard palate [5]. Ulcerative form of SCC is locally destructive; thereby timely and correct diagnosis of oral SCC plays a key role 
in the improvement of patients prognosis and survival rate $[3,55]$. There is no single treatment for oral SCC; however, various therapeutic modalities from surgery, radiotherapy, and chemotherapy to combination different methods have been introduced [54].

Cytomegalovirus-Associated Ulceration. Cytomegalovirus (CMV) is a member of herpes virus group. About $80 \%$ of adults have serologic evidence of CMV infection without clinical outcome. Cytomegalovirus-related ulcers occur more commonly under conditions of significant immunodeficiency, especially severe $\operatorname{HIV}$ disease [3, 55]. Oral ulcers are usually single, painful, large, and necrotic, with minimally rolled border, which affects keratinized and nonkeratinized mucosa. On rare occasions, multiple ulcerations are seen $[3,20]$. CMV ulcers might last for several weeks or months. Treatment can be accomplished by valganciclovir, ganciclovir, or cidofovir. Topical anesthesia or systemic analgesics might be useful for pain relief. Good hydration and dietary modification should also be considered [3].

Tuberculous Ulcer. Some granulomatous diseases such as tuberculosis and leprosy can cause ulcerative lesions in the oral cavity [23, 56, 57]. The World Health Organization (WHO) has estimated 9.4 million incident cases and 11.1 million prevalent cases of TB globally $[23,57]$. Tuberculosis rarely affects oral mucosa, roughly $1.4 \%$ of all $\mathrm{TB}$ cases with a male to female ratio of $4: 1$ [23]. The classic oral lesion presents as a solitary ulcer usually with an undermined edge most commonly on the tongue, followed by gingivae, floor of the mouth, palate, lips, and buccal mucosa. Meanwhile, it may be ragged and indurated and is often painful $[24,25]$. The differential diagnosis of tuberculous ulcer includes traumatic ulcer, syphilitic ulcer, and oral SCC [24].

Syphilitic Ulceration (Chancre). Primary syphilitic ulceration usually occurs as a result of orogenital or oroanal contact with an infectious lesion. It rarely affects the mouth and often remains undiagnosed because of its temporary duration. Almost one to three weeks after acquisition, a chancre develops as a solitary ulcer usually on the lips or rarely on the tongue, pharynx, or tonsils. The upper lip is more commonly affected in males and the lower lip in females, probably due to the anatomy involved with fellatio and cunnilingus. The ulceration is usually deep, with a red purple or brown base ragged rolled border, and usually an accompanying cervical lymphadenopathy. Traumatic ulceration and squamous cell carcinoma might be quite similar to syphilitic chancre. Detailed history of sexual and social life style helps approach the diagnosis of primary syphilis $[26,58,59]$.

Deep Fungal Ulceration (Histoplasmosis, Blastomycosis, and Mucormycosis). Oral mucosal lesion in histoplasmosis is usually secondary to pulmonary involvement and occurs in a significant percentage of patients with disseminated histoplasmosis. It begins as an area of erythema that converts to a granulomatous ulcer.
The most frequent feature of oral blastomycosis is a nonspecific, painless, verrucous ulcer with indurated borders, often mistaken for oral SCC.

The most common oral sign of mucormycosis is ulceration of the palate, which results from necrosis due to invasion of a palatal vessel. Lesion has also been observed on the gingivae, lips, and alveolar ridge [3].

\subsubsection{Multiple Chronic Ulcers}

Vesiculobullous Diseases. Some vesiculobullous diseases such as pemphigus vulgaris (PV), mucous membrane pemphigoid (MMP), and bullous pemphigoid (BP) present as multiple and chronic oral ulcerative lesions [3].

Pemphigus vulgaris (PV) is a chronic vesiculobullous mucocutaneous autoimmune disease characterized by loss of cell adhesion (acantholysis) and blister formation [60]. About $90 \%$ of patients with PV develop oral lesions, and in more than $50 \%$ of cases they are the first sign of disease. Oral lesions begin as bullae on noninflamed base. More frequently, clinicians notice shallow irregular ulcers, because the bullae rapidly rupture. The edge of lesions continues to extend over a period of weeks until they involve large areas of oral cavity. The lesions usually start on the buccal mucosa; however, palate and gingivae are other commonly affected sites. Gingival involvement might be in the form of desquamative gingivitis, which is a characteristic feature for PV [3]. Oral lesions appear several months predating skin lesions $[3,27]$. Final diagnosis often takes more than 5 months from the onset of disease. Meanwhile, coexisting candidiasis may mask the typical features of PV lesions. There is a small group of PV patients whose disease remains confined to the oral cavity. These patients often have negative results on direct and indirect immunofluorescence testing [3]. Early diagnosis is an important aspect of patient management when lower doses of medication can be used for shorter periods of time to control the disease. The mainstay of treatment remains high doses of systemic corticosteroids, usually given in dosages of 1 to $2 \mathrm{mg} / \mathrm{kg} / \mathrm{d}[3,60]$.

Mucous membrane pemphigoid (MMP) has been known by different names including benign mucous membrane pemphigoid, cicatricial (scarring) pemphigoid, and ocular cicatricial pemphigoid [61]. MMP is a common immunemediated subepithelial blistering disease mainly affecting oral mucosa (over 90\%); however, skin lesions are also present in $20 \%$ to $30 \%$ of cases. The most affected site in the oral cavity is gingivae followed by buccal mucosa and palate. It occurs twice as frequently in females and is generally seen in patients more than 50 years old $[3,5,62,63]$. Desquamative gingivitis is the most common presentation of the disease, which can be the only feature of MMP. Blood blisters which result from bleeding into bullae are a diagnostic feature of MMP in the oral cavity. Use of topical or systemic corticosteroids is considered as an acceptable treatment for MMP. Furthermore, when there is ocular involvement dapsone therapy is recommended [3].

Bullous pemphigoid (BP) is the most common subepithelial blistering disease, which occurs chiefly in patients over the age of 60 [3]. In this entity, oral mucosal involvement 
is not common. According to Budimir et al., oral mucosal lesions are found in only $16.6 \%$ of cases [64], which are similar to PV but are smaller and less painful. Meanwhile, extensive labial involvement which is common in PV is not present in BP. Desquamative gingivitis has been mentioned as the most frequent oral manifestation in $\mathrm{BP}$ and gingivae may be the only affected site [3]. Clinically, oral lesions are not distinguishable from PV or MMP, but early remission of BP is more common $[64,65]$. Noteworthy, BP has been reported in conjunction with other diseases such as multiple sclerosis, malignancies, or medications particularly diuretics [3]. Bullous pemphigoid is self-limiting and may last from a few months to 5 years. Topical clobetasol or betamethasone has been suggested in the management of localized oral lesions, whereas, in more extensive disease, use of systemic corticosteroids alone or in combination with immunosuppressive drugs is recommended $[3,64]$.

Lichen Planus (LP). Lichen planus (LP) is a chronic, autoimmune, mucocutaneous disease. Most LP patients are middleaged, and it is rare in children. The disease occurs more commonly in women than in men with a female/male ratio of approximately $2: 1$. The reported prevalence of LP is up to $5 \%$, while the prevalence of oral LP (OLP) is $0.1 \%$ to $2.2 \%[28,66]$. OLP may occur alone or in combination with skin or other mucosal involvement [28]. There are different subtypes of OLP with different clinical presentations: reticular (lace-like keratotic mucosal configuration, Wickham's striae), atrophic (keratotic changes combined with mucosal erythema), erosive/ulcerative (pseudomembrane covered ulcerations combined with keratosis and erythema), bullous (vesiculobullous presentation combined with reticular or erosive patterns), and popular/plaque like (keratotic changes with elevation adjacent to the normal mucosa) (Figure 9). Reticular, popular, and plaque-like lesions are generally asymptomatic whereas bullous, erosive and ulcerative forms are generally associated with pain. Atrophic or erosive LP involving the gingivae results in desquamative gingivitis. This condition has been also found in MMP and PV [3]. The most frequently affected site in the oral cavity is buccal mucosa, followed by the tongue, gingivae, palate, and vermilion border [66]. OLP is considered a premalignant lesion. The risk of malignancy has been estimated to be $0.4 \%-3.7 \%$, which often develops after 10 years. Hence, OLP should be followed up for a long time. Topical or systemic corticosteroids are usually recommended in management of OLP [66].

Linear IgA Disease. Linear IgA disease (LAD) or linear IgA dermatitis is an autoimmune subepithelial mucocutaneous disease. LAD affects both adults and children. Peak of incidence is between sixth and seventh decades of life in adult patients, with a twofold predilection for females. The pediatric variant is called chronic bullous dermatitis of childhood or juvenile dermatitis herpetiform [67]. Oral involvement in LAD has been estimated to be between $5 \%$ and $70 \%$ in the form of vesicles, painful ulcerations or erosions, and erosive gingivitis/cheilitis. The most common affected site in the oral cavity is hard and soft palate, followed by tonsillar pillars, buccal mucosa, tongue, and gingivae [68]. In a case report

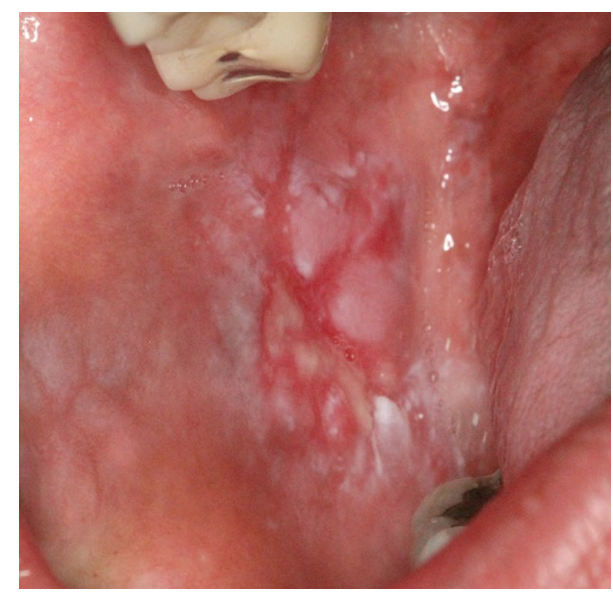

FIGURE 9: Ulcerative lichen planus on the buccal mucosa presenting as a central ulcer with pseudomembrane and keratotic plaques at the periphery.

by Chan et al., oral lesions were the only presentation of LAD for 5 years [69]. Oral lesions are usually managed with the use of topical steroids, but dapsone therapy for more severe cases is recommended. Resistant cases may require systemic corticosteroids [3].

\subsubsection{Recurrent Ulcers (Solitary/Multiple)}

Recurrent Aphthous Stomatitis. Recurrent aphthous stomatitis (RAS) is the most common inflammatory disease of the oral mucosa with a global prevalence of $0.5 \%$ to $75 \%$ and female predilection [70]. The first episode of RAS most frequently commences in the second decade of life. The lesions usually begin with prodromal burning sensation 2 to 48 hours before an ulcer appears [3]. Oral aphthous ulcers typically occur as painful, symmetrically round fibrin-covered mucosal defects with an erythematous border and most commonly on nonkeratinized mucosa in healthy patients (Figure 10). However, it can be seen on the keratinized mucosa especially in patients with immune deficiency. Three clinical types of RAS have been identified: minor-type (Mikulicz) is smaller than $1 \mathrm{~cm}$ in diameter (usually $2-3 \mathrm{~mm}$ ) and heals spontaneously in two weeks. This type constitutes $80-90 \%$ of all aphthous ulcers. Major-type (Sutton ulcer) is usually $1-3 \mathrm{~cm}$ in size, and lasts for 10 days to 6 weeks or even longer. More than $60 \%$ of Sutton ulcers heal with scarring. Major type accounts for about $10 \%$ of RAS. Herpetiform aphthae appears as very small (1-2 mm), extremely painful, and numerous ulcers (up to 100 lesions). About $32 \%$ of lesions heal with scarring [70, 71]. Diagnosis is based on patient's history and pattern of ulcers. Laboratory evaluation is mandatory when (a) episodes of lesions become more severe, (b) lesions begin after the age of 25 , and (c) general symptoms are accompanied by lesions [3]. RAS is self-limiting, but in severe cases topical or systemic corticosteroids are recommended $[70,71]$.

Recurrent Herpes Stomatitis. Herpes simplex virus can establish latency in the trigeminal ganglia and periodically reactivate to cause recurrent herpetic stomatitis (RHS). There 


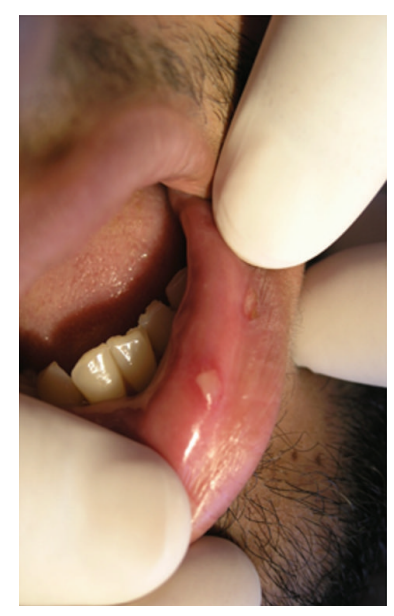

FIGURE 10: Recurrent aphthous stomatitis as a symmetrical ulcer with pseudomembrane and inflammatory halo.

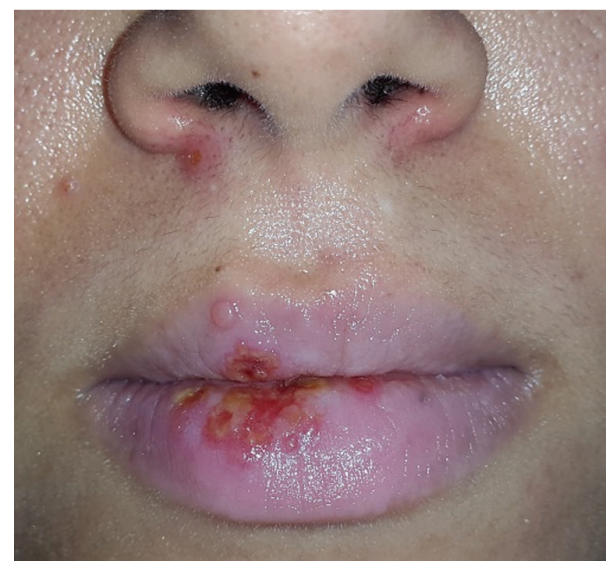

FIGURE 11: Recurrent herpes labialis presented as multiple vesicles and scalloped-border erosions coated with crust.

are two subgroups: recurrent herpes simplex labialis (HSL) (Figure 11), which is more commonly seen in healthy subjects. It begins as vesicles that rupture soon, which leave superficial crusted ulcers and heal without scarring. Recurrent intraoral herpes (RIH) is more common in immunocompromised patients. However, RIH in immune competent patients is limited to the keratinized mucosa, especially on the hard palate usually as clustered and unilateral vesicles. Common triggers of RHS are physical/emotional stress, UV light, cold weather, hormonal changes, upper respiratory tract illness, and lip/mouth trauma [3,72]. Although the lesions are self-limiting, symptomatic treatment by using ice or lanolin is recommended. Applying acyclovir ointment 5\% every 2 hours since the prodromal phase until the lesions subside has been suggested as well. Elective dental treatments should be deferred in patients with active lesions to prevent aerosolization of the virus [71].

Herpes-Associated Erythema Multiform. Erythema multiform (EM) can be induced by several infectious agents, in particular HSV [73, 74]. According to Ng et al., HSV DNA has been detected in $50 \%$ of patients with recurrent idiopathic EM [74] typically affecting young adults (20-40 years) and is more common in men with the ratio of $3: 2$ [73]. It can be found several days or weeks following an episode of HSV, and the lips are mostly affected [73]. The diagnosis is based on clinical features and is more straightforward when target lesions with preceding or coexisting HSV infection present. History of recurrence has been found in $25 \%$ of all EM cases. Patients usually experience 2 to 24 episodes in a year. The duration of disease ranges from 2 to 36 years (mean of 10 years). Acyclovir ( $200 \mathrm{mg}$, 5 times a day, for 5 days) is recommended for management of lesions [73].

Cyclic Neutropenia. Cyclic neutropenia (CN) is an immunodeficiency syndrome, characterized by regular periodic oscillations in the circulating neutrophil count from normal to neutropenic levels every 21 days, and lasting for 3-6 days. Patients with cyclic neutropenia are usually asymptomatic but during neutropenic episodes suffer from fever of unknown origin, gingivitis, stomatitis, aphthous-like ulceration, cellulitis, perirectal abscess, and severe systemic pyogenic infections [75]. The severity and recurrence of oral ulcers in $\mathrm{CN}$ are similar to those of ulcers in major RAS; additionally, periodontal destruction in $\mathrm{CN}$ is as severe as what is seen in aggressive periodontitis [29].

Behçet's Disease. Behçet's disease (BD) is a systemic immunemediated vasculitis characterized by the presence of recurrent oral and genital ulcers, ocular inflammation, and skin lesions. The etiology and pathogenesis of BD are unknown. BD can affect any age groups, but onset before puberty and after the sixth decade of life is relatively rare. The most common age of presentation is around the third decade of life, with a balanced male/female ratio. Recurrent and painful oral ulcers are present in $90 \%$ to $100 \%$ of patients with BD. The diagnosis of $\mathrm{BD}$ is based on clinical criteria. Presence of recurrent oral aphthous-like ulcers (minor, major, or herpetiform ulcers, which recur at least three times within a period of 12 months) along with two of the following: genital ulcers, ocular lesions (anterior uveitis, posterior uveitis, vitreous cellularity, or retinal vasculitis), and skin lesions (erythema nodosum, pseudofolliculitis or papulopustular lesions, or acneiform papulae in postadolescent patients without any steroid treatment, and positive pathergy test) establishes the diagnosis [30-32]. Glucocorticoids, colchicine, azathioprine, cyclosporine, tacrolimus, anti-TNF-alpha (infliximab and etanercept), thalidomide, and rituximab are all recommended for treatment. Topical corticosteroids are not optimally effective against oral lesions. Treatment with infliximab causes complete resolution of recurrent oral ulcers [30].

\section{Discussion}

Oral ulcerative lesions are categorized into solitary acute, multiple acute, solitary chronic, multiple chronic, and recurrent lesions.

Acute oral ulcerations result from traumatic insults, viral or bacterial infections, allergy, or cancer chemotherapy. 
Acute traumatic ulcers usually present as solitary lesions of nonspecific clinical shapes (Figure 3) [11, 12], whereas viral stomatitis appear as multiple small symmetrical ulcers, which sometimes coalesce to form larger lesions with scalloped borders (Figure 4) [11,13]. Allergic stomatitis tend to involve any site intraorally with various clinical features usually with a history of synchronous exposure to contactants or systemic allergens $[3,44]$. Although chemotherapy-induced stomatitis can be quite diffuse, its commencement is chronologically related to therapeutic agents, which differentiate it from other acute oral ulcerations [46, 47]. Some bacterial stomatitis present as either acute multiple punched- out necrotic ulcerations (e.g., NUG and NUP) (Figure 6) in patients with malnutrition or immunocompromised state $[19,43]$, or single chronic ulceration of which tuberculous ulcer presents as an undermined lesion [24]. When confronting a single chronic ulcer, it would appear to be prudent to preclude oral squamous cell carcinoma (Figure 8) first due to its poor prognosis and grave morbidity $[5,22]$. In addition, in the category of solitary chronic ulcers, history of lung disease or dealing with animals propose histoplasmosis or blastomycosis, while presence of debilitating disease such as diabetes mellitus suggest mucormycosis [3]. On the other hand, multiple map-like or asymmetrical ulcerations suggest the presence of mucocutaneous vesiculobullous diseases; among them, pemphigus is of high potency for extension, which might lead to death $[3,27]$. Despite chronic lesions with ongoing progression or sustained clinical features a history of repeated resolution and relapse prompts the clinician to rank recurrent oral ulcerations higher in the differential diagnosis. Recurrent aphthous stomatitis (Figure 10) and recurrent herpes are two common entities in this category with the former being more frequent in the nonkeratinized mucosa and the latter in the keratinized mucosa $[3,27]$.

\section{Conclusion}

The newly updated decision tree includes 29 oral ulcerative lesions based on duration and number of lesions, which helps clinicians establish a stepwise method to rule out improbable conditions to arrive at a logical diagnosis.

\section{Competing Interests}

The authors declare that there is no conflict of interests regarding the publication of this paper.

\section{Acknowledgments}

The authors are greatly thankful to Dr. Hamid Reza Khalighi for providing the pictures.

\section{References}

[1] M. Muñoz-Corcuera, G. Esparza-Gómez, M. A. GonzálezMoles, and A. Bascones-Martínez, "Oral ulcers: clinical aspects. A tool for dermatologists. Part I. Acute ulcers," Clinical and Experimental Dermatology, vol. 34, no. 3, pp. 289-294, 2009.
[2] M. Muñoz-Corcuera, G. Esparza-Gómez, M. A. GonzálezMoles, and A. Bascones-Martínez, "Oral ulcers: clinical aspects. A tool for dermatologists. Part II. Chronic ulcers," Clinical and Experimental Dermatology, vol. 34, no. 4, pp. 456-461, 2009.

[3] M. S. Greenberg, M. Glick, and J. A. Ship, Burket's Oral Medicine, BC Decker, Hamilton, Canada, 2008.

[4] A. J. Bruce, T. S. Dabade, and N. M. Burkemper, "Diagnosing oral ulcers ," Journal of the American Academy of Physician Assistants, vol. 28, pp. 1-10, 2015.

[5] N. K. Wood and P. W. Goaz, Eds., Differential Diagnosis of Oral and Maxillofacial Lesions, Mosby, St Luis, Mo, USA, 1997.

[6] V. B. Valente, A. S. Takamiya, L. L. Ferreira et al., "Oral squamous cell carcinoma misdiagnosed as a denture-related traumatic ulcer: a clinical report," The Journal of Prosthetic Dentistry, vol. 115, no. 3, pp. 259-262, 2016.

[7] F. de Sant' Ana dos Santos, M. A. Isper, J. P. Novo-Neto et al., "Misdiagnosis of lip squamous cell carcinoma," RSBO, vol. 9, pp. 114-118, 2012.

[8] P. S. Kumari, G. P. Kumar, Y. D. Bai, and E. Y. R. B. N. Reddy, "Gingival squamous cell carcinoma masquerading as an aphthous ulcer," Journal of Indian Society of Periodontology, vol. 17, no. 4, pp. 523-526, 2013.

[9] M. W. Finkelstein, "A guide to the clinical differential diagnoses of oral mucosal lesions," Crest ${ }^{\circledR}$ Oral- ${ }^{\circledR}$ at dentalcare.com, Continuing Education Course, pp. 1-41, 2010.

[10] M. A. Kahn and J. M. Hall, The ADA Practical Guide to Soft Tissue Oral Disease, Wiley-Blackwell, Hoboken, NJ, USA, 2014.

[11] B. W. Neville, D. D. Damm, C. M. Allen, and J. E. Bouquot, Oral and Maxillofacial Pathology, Sunders, St Luis, Mo, USA, 2002.

[12] J.-Y. Chen, W.-C. Wang, Y.-K. Chen, and L.-M. Lin, "A retrospective study of trauma-associated oral and maxillofacial lesions in a population from southern Taiwan," Journal of Applied Oral Science, vol. 18, no. 1, pp. 5-9, 2010.

[13] M. J. McCullough and N. W. Savage, "Oral viral infections and the therapeutic use of antiviral agents in dentistry," Australian Dental Journal, vol. 50, supplement 2, pp. S31-S35, 2005.

[14] J. N. R. Assunção and G. D. Rabelo, "Images in clinical medicine. Lesions in the oral cavity," The New England Journal of Medicine, vol. 368, no. 8, article e10, 2013.

[15] N. Guttiganur, A. Devanoorkar, S. Aspalli, and S. Shetty, "Herpes zoster of trigeminal nerve after dental extraction," Indian Journal of Dental Research, vol. 24, article 396, 2013.

[16] J. Puenpa, J. Mauleekoonphairoj, P. Linsuwanon et al., "Prevalence and characterization of enterovirus infections among pediatric patients with hand foot mouth disease, herpangina and influenza like illness in Thailand, 2012," PLoS ONE, vol. 9, no. 6, Article ID e98888, 2014.

[17] K.-T. Chen, H.-L. Chang, S.-T. Wang, Y.-T. Cheng, and J.-Y. Yang, "Epidemiologic features of hand-foot-mouth disease and herpangina caused by enterovirus 71 in Taiwan, 1998-2005," Pediatrics, vol. 120, no. 2, pp. e244-e252, 2007.

[18] K. A. Al-Johani, S. Fedele, and S. R. Porter, "Erythema multiforme and related disorders," Oral Surgery, Oral Medicine, Oral Pathology, Oral Radiology and Endodontology, vol. 103, no. 5, pp. 642-654, 2007.

[19] Y. Mizrahi, "NUG—necrotizing ulcerative gingivitis: a review," Refuat Hapeh Vehashinayim, vol. 31, no. 3, pp. 41-62, 2014.

[20] R. A. Cawson and E. W. Odel, Eds., Cawson's Essentials of Oral Pathology and Oral Medicine, Churchil Livingstone, St. Louis, Mo, USA, 2002. 
[21] W.-R. Shen, J.-Y. Chang, Y.-C. Wu, S.-J. Cheng, H.-M. Chen, and Y.-P. Wang, "Oral traumatic ulcerative granuloma with stromal eosinophilia: a clinicopathological study of 34 cases," Journal of the Formosan Medical Association, vol. 114, no. 9, pp. 881-885, 2015.

[22] Q. G. Fang, S. Shi, Z. N. Li et al., "Squamous cell carcinoma of the buccal mucosa: analysis of clinical presentation, outcome and prognostic factors," Molecular and Clinical Oncology, vol. 1, pp. 531-534, 2013.

[23] H. Ram, S. Kumar, S. Mehrotra, and S. Mohommad, "Tubercular ulcer: mimicking squamous cell carcinoma of buccal mucosa," Journal of Maxillofacial and Oral Surgery, vol. 11, no. 1, pp. 105-108, 2012.

[24] O. K. Kakisi, A. S. Kechagia, I. K. Kakisis, P. I. Rafailidis, and M. E. Falagas, "Tuberculosis of the oral cavity: a systematic review," European Journal of Oral Sciences, vol. 118, no. 2, pp. 103-109, 2010.

[25] M. D. Mignogna, L. L. Muzio, G. Favia et al., "Oral tuberculosis: a clinical evaluation of 42 cases," Oral Diseases, vol. 6, no. 1, pp. 25-30, 2000.

[26] J. C. Leão, L. A. Gueiros, and S. R. Porter, "Oral manifestations of syphilis,” Clinics, vol. 61, no. 2, pp. 161-166, 2006.

[27] F. Camacho-Alonso, P. López-Jornet, and A. Bermejo-Fenoll, "Pemphigus vulgaris. A presentation of 14 cases and review of the literature," Medicina Oral, Patologia Oral y Cirugia Bucal, vol. 10, no. 4, pp. 282-288, 2005.

[28] J. Wang and I. van der Waal, "Disease scoring systems for oral lichen planus; a critical appraisal," Medicina Oral, Patologia Oral y Cirugia Bucal, vol. 20, no. 2, Article ID 20524, pp. e199-e204, 2015.

[29] Y. Chen, L. Fang, and X. Yang, "Cyclic neutropenia presenting as recurrent oral ulcers and periodontitis," Journal of Clinical Pediatric Dentistry, vol. 37, no. 3, pp. 307-308, 2013.

[30] C. Morales-Angulo, S. Vergara Pastrana, S. Obeso-Agüera, L. Acle, and M. Á. González-Gay, "Otorhinolaryngological manifestations in patients with Behçet disease," Acta Otorrinolaringologica Espanola, vol. 65, no. 1, pp. 15-21, 2014.

[31] D. M. G. Main and M. A. Chamberlain, "Clinical differentiation of oral ulceration in Behçet's disease," British Journal of Rheumatology, vol. 31, no. 11, pp. 767-770, 1992.

[32] "Criteria for diagnosis of Behçet's disease. International Study Group for Behçet's Disease," The Lancet, vol. 335, no. 8697, pp. 1078-1080, 1990.

[33] D. Compilato, G. Corsello, and G. Campisi, "An unusual traumatic ulceration of the tongue," Journal of Paediatrics and Child Health, vol. 48, no. 12, pp. 1104-1105, 2012.

[34] F. L. Femopase, S. L. Hernández, H. Gendelman, M. I. Criscuolo, and S. A. López De Blanc, "Necrotizing sialometaplasia: report of five cases," Medicina Oral, vol. 9, no. 4, pp. 304308, 2004.

[35] R. P. S. Mohan, S. Verma, U. Singh, and N. Agarwal, "Acute primary herpetic gingivostomatitis," BMJ Case Reports, vol. 2013, 2013.

[36] V. Noonan, M. A. Lerman, S.-B. Woo, and S. Kabani, "Acute primary herpetic gingivostomatitis," Journal of the Massachusetts Dental Society, vol. 63, article 51, 2014.

[37] S. Patil, K. Srinivas, B. S. Reddy, and M. Gupta, "Prodromal herpes zoster mimicking odontalgia-a diagnostic challenge," Ethiopian Journal of Health Sciences, vol. 23, no. 1, pp. 73-77, 2013.
[38] J. G. Donahue, P. W. Choo, J. E. Manson, and R. Platt, "The incidence of herpes zoster," Archives of Internal Medicine, vol. 155, no. 15, pp. 1605-1609, 1995.

[39] S. Chatproedprai, A. Theanboonlers, S. Korkong, C. Thongmee, S. Wananukul, and Y. Poovorawan, "Clinical and molecular characterization of hand-foot-and-mouth disease in Thailand, 2008-2009," Japanese Journal of Infectious Diseases, vol. 63, no. 4, pp. 229-233, 2010.

[40] R. L. V. Osterne, R. G. D. Matos Brito, I. A. Pacheco, A. P. N. N. Alves, and F. B. Sousa, "Management of erythema multiforme associated with recurrent herpes infection: a case report," Journal of the Canadian Dental Association, vol. 75, no. 8, pp. 597-601, 2009.

[41] M. R. Lamoreux, M. R. Sternbach, and W. T. Hsu, "Erythema multiforme," American Family Physician, vol. 74, no. 11, pp. 1883-1888, 2006.

[42] S. Nanda, D. Pandhi, and B. S. N. Reddy, "Erythema multiforme in a 9-day-old neonate," Pediatric Dermatology, vol. 20, no. 5, pp. 454-455, 2003.

[43] R. Atout and S. Todescan, "Managing patients with necrotizing ulcerative gingivitis," Journal of the Canadian Dental Association, vol. 79, article d46, 2013.

[44] P. Satpute, L. Yadav, R. Ahmed, A. Kashid, and K. Peter, "Herbal toothpowder induced erythema multiforme," Journal of Clinical and Diagnostic Research, vol. 8, no. 3, pp. 275-276, 2014.

[45] T. Inozume, R. Nakazawa, K. Tanaka et al., "A case of oral mucosal fixed eruption caused by methacrylate," Contact Dermatitis, vol. 70, no. 6, pp. 387-388, 2014.

[46] R. H. Barrach, M. P. de Souza, D. P. C. da Silva, P. S. Lopez, and J. C. Montovani, "Oral changes in individuals undergoing hematopoietic stem cell transplantation," Brazilian Journal of Otorhinolaryngology, vol. 81, no. 2, pp. 141-147, 2015.

[47] D. A. Kolbinson, M. M. Schubert, N. Flournoy, and E. L. Truelove, "Early oral changes following bone marrow transplantation," Oral Surgery, Oral Medicine, Oral Pathology, vol. 66, no. 1, pp. 130-138, 1988.

[48] S. T. Sonis, K. E. O'Donnell, R. Popat et al., "The relationship between mucosal cyclooxygenase-2 (COX-2) expression and experimental radiation-induced mucositis," Oral Oncology, vol. 40, no. 2, pp. 170-176, 2004.

[49] S. Dreizen, K. B. McCredie, G. P. Bodey, and M. J. Keating, "Quantitative analysis of the oral complications of antileukemia chemotherapy," Oral Surgery, Oral Medicine, Oral Pathology, vol. 62, no. 6, pp. 650-653, 1986.

[50] G. L. Pattison, "Self-inflicted gingival injuries: literature review and case report," Journal of Periodontology, vol. 54, no. 5, pp. 299-304, 1983.

[51] A. T. Zonuz, N. Treister, F. Mehdipour, R. Mostofizadeh Farahani, R. S. Tubbs, and M. Mohajel Shoja, "Factitial pemphiguslike lesions," Medicina Oral, Patología Oral y Cirugía Bucal, vol. 12, no. 3, pp. E205-E208, 2007.

[52] P. Kivovics, M. Jáhn, J. Borbély, and K. Márton, "Frequency and location of traumatic ulcerations following placement of complete dentures," The International Journal of Prosthodontics, vol. 20, no. 4, pp. 397-401, 2007.

[53] S. Chandra, S. Raju, K. Sah, and P. Anand, "Traumatic ulcerative granuloma with stromal eosinophilia," Archives of Iranian Medicine, vol. 17, no. 1, pp. 91-94, 2014.

[54] M. Zargaran, N. Eshghyar, P. B. Vaziri, and H. Mortazavi, "Immunohistochemical evaluation of type IV collagen and laminin-332 $\gamma 2$ chain expression in well-differentiated oral 
squamous cell carcinoma and oral verrucous carcinoma: a new recommended cut-off," Journal of Oral Pathology and Medicine, vol. 40, no. 2, pp. 167-173, 2011.

[55] J. C. Leão, V. B. Gomes, and S. Porter, "Ulcerative lesions of the mouth: an update for the general medical practitioner," Clinics, vol. 62, no. 6, pp. 769-780, 2007.

[56] J.-B. Taheri, H. Mortazavi, M. Moshfeghi et al., "Oro-facial manifestations of 100 leprosy patients," Medicina Oral, Patologia Oral y Cirugia Bucal, vol. 17, no. 5, pp. e728-e732, 2012.

[57] F. Babazade, H. Mortazavi, and H. Jalalian, "Parotid tuberculosis: a forgotten suspicion (a case report and literature review)," International Journal of Dermatology, vol. 51, no. 5, pp. 588-591, 2012.

[58] N. Meljanac, E. Dippel, and C. C. Zouboulis, "Superimposed primary chancre in a patient with Adamantiades-Behcet's disease," Sexually Transmitted Infections, vol. 75, no. 2, pp. 124-125, 1999.

[59] H. Kirwald and A. Montag, "Stage 3 syphilis of the mouth cavity," Laryngorhinootologie, vol. 78, no. 5, pp. 254-258, 1999.

[60] N. Esmaili, H. Mortazavi, P. Noormohammadpour et al., "Pemphigus vulgaris and infections: a retrospective study on 155 patients," Autoimmune Diseases, vol. 2013, Article ID 834295, 5 pages, 2013.

[61] A. P. R. Singh, T. R. Chaitra, T. L. Ravishankar, S. P. R. Singh, and A. K. U. Mohapatra, "HIV patient with mucous membrane pemphigoid: a case report," Ethiopian Journal of Health Sciences, vol. 24, no. 2, pp. 179-182, 2014.

[62] P. Kanjanabuch, S. Arporniem, S. Thamrat, and P. Thumasombut, "Mucous membrane pemphigoid in a patient with hypertension treated with atenolol: a case report," Journal of Medical Case Reports, vol. 6, article 373, 2012.

[63] E. Parisi, S. Raghavendra, V. P. Werth, and T. P. Sollecito, "Modification to the approach of the diagnosis of mucous membrane pemphigoid: a case report and literature review," Oral Surgery, Oral Medicine, Oral Pathology, Oral Radiology, and Endodontics, vol. 95, no. 2, pp. 182-186, 2003.

[64] J. Budimir, L. L. Mihić, M. Šitum, V. Bulat, S. Peršić, and M. Tomljanović-Veselski, "Oral lesions in patients with pemphigus vulgaris and bullous pemphigoid," Acta Clinica Croatica, vol. 47, no. 1, pp. 13-18, 2008.

[65] L. Vaillant, "Bullous autoimmune diseases of the oral mucosa," Revue de Stomatologie et de Chirurgie Maxillo-Faciale, vol. 100, no. 5, pp. 230-239, 1999.

[66] H. Mortazavi, M. Baharvand, and M. Mehdipour, "Oral potentially malignant disorders: an overview of more than 20 entities," Journal of Dental Research, Dental Clinics, Dental Prospects, vol. 8, no. 1, pp. 6-14, 2014.

[67] F. Angiero, S. Benedicenti, R. Crippa, S. Magistro, D. Farronato, and M. Stefani, "A rare case of desquamative gingivitis due to linear IgA disease: morphological and immunofluorescence features," In Vivo, vol. 21, no. 6, pp. 1093-1098, 2007.

[68] D. M. Cohen, I. Bhattacharyya, S. L. Zunt, and C. E. Tomich, "Linear IgA disease histopathologically and clinically masquerading as lichen planus," Oral Surgery, Oral Medicine, Oral Pathology, Oral Radiology, and Endodontics, vol. 88, no. 2, pp. 196-201, 1999.

[69] L. S. Chan, J. A. Regezi, and K. D. Cooper, "Oral manifestations of linear IgA disease," Journal of the American Academy of Dermatology, vol. 22, no. 2, pp. 362-365, 1990.

[70] M. W. Liang and C. Y. Neoh, "Oral aphthosis: management gaps and recent advances," Annals of the Academy of Medicine Singapore, vol. 41, no. 10, pp. 463-470, 2012.
[71] A. Altenburg, N. El-Haj, C. Micheli, M. Puttkammer, M. B. Abdel-Naser, and C. C. Zouboulis, "The treatment of chronic recurrent oral aphthous ulcers," Deutsches Ärzteblatt International, vol. 111, no. 40, pp. 665-673, 2014.

[72] E. T. Stoopler, A. S. Kuperstein, and T. P. Sollecito, "How do I manage a patient with recurrent herpes simplex?" Journal of the Canadian Dental Association, vol. 78, article c154, 2012.

[73] R. L. V. Osterne, R. G. D. Matos Brito, I. A. Pacheco, A. P. N. N. Alves, and F. B. Sousa, "Management of erythema multiforme associated with recurrent herpes infection: a case report," Journal of Canadian Dental Association, vol. 75, no. 8, pp. 597-601, 2009.

[74] P. P. L. Ng, Y. J. Sun, H. H. Tan, and S. H. Tan, "Detection of herpes simplex virus genomic DNA in various subsets of erythema multiforme by polymerase chain reaction," Dermatology, vol. 207, no. 4, pp. 349-353, 2003.

[75] N. Rezaei, A. Farhoudi, Z. Pourpak et al., "Clinical and laboratory findings in Iranian children with cyclic neutropenia," Iranian Journal of Allergy, Asthma and Immunology, vol. 3, no. 1, pp. 37-40, 2004. 


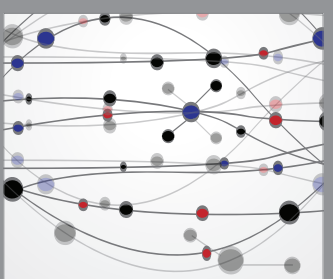

The Scientific World Journal
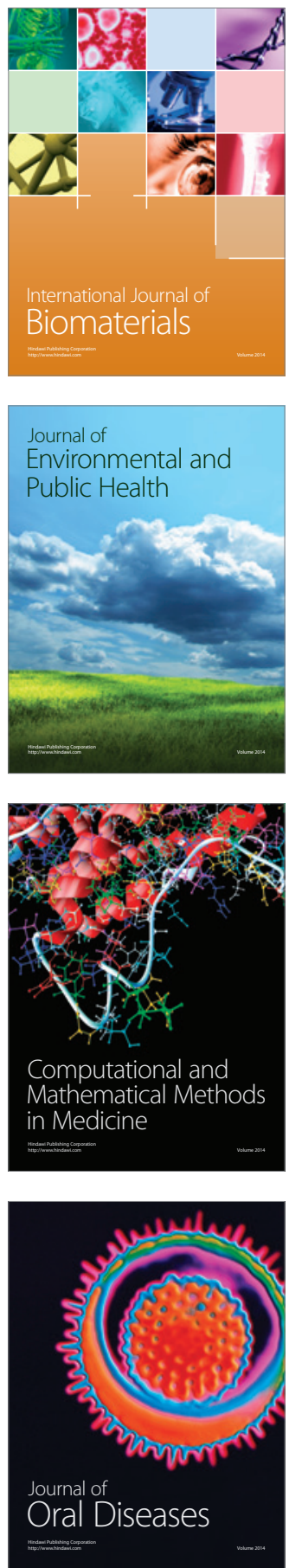
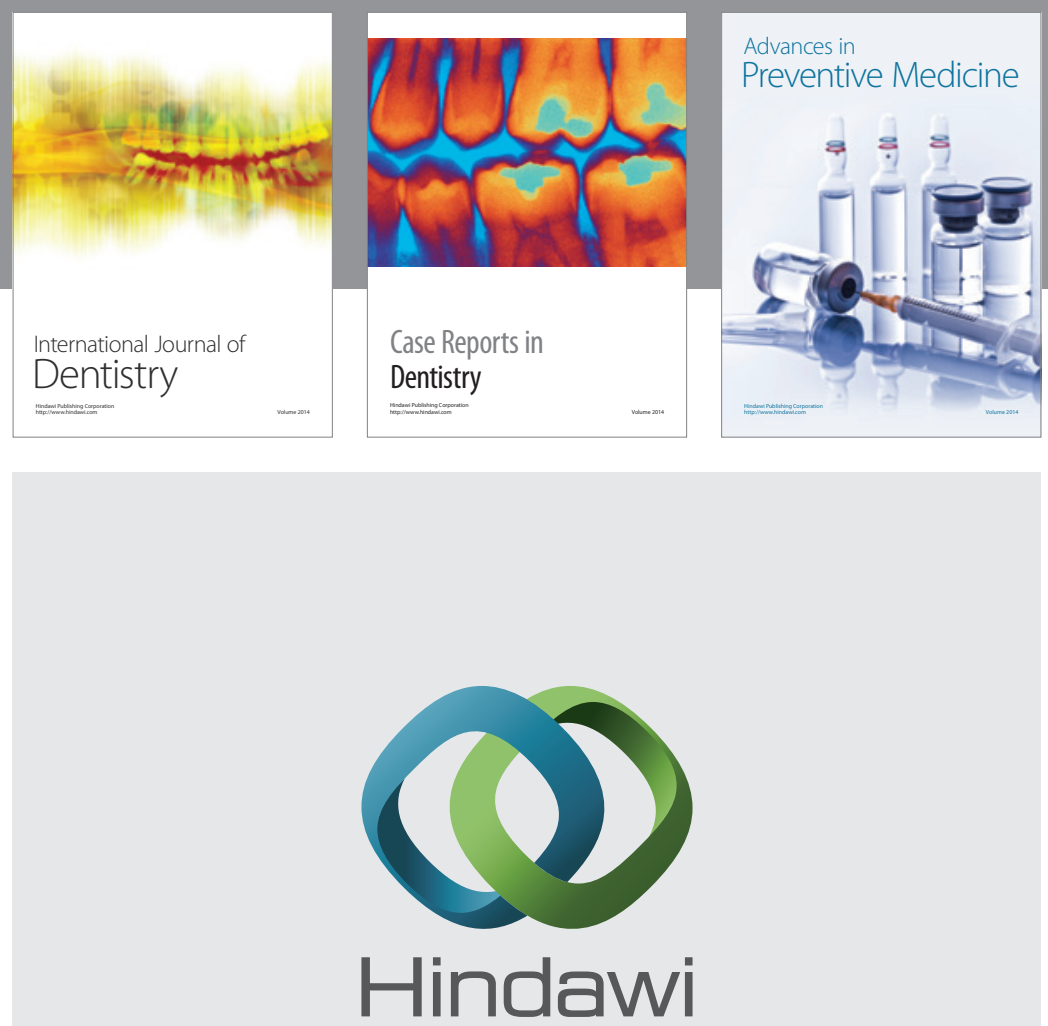

Submit your manuscripts at

http://www.hindawi.com
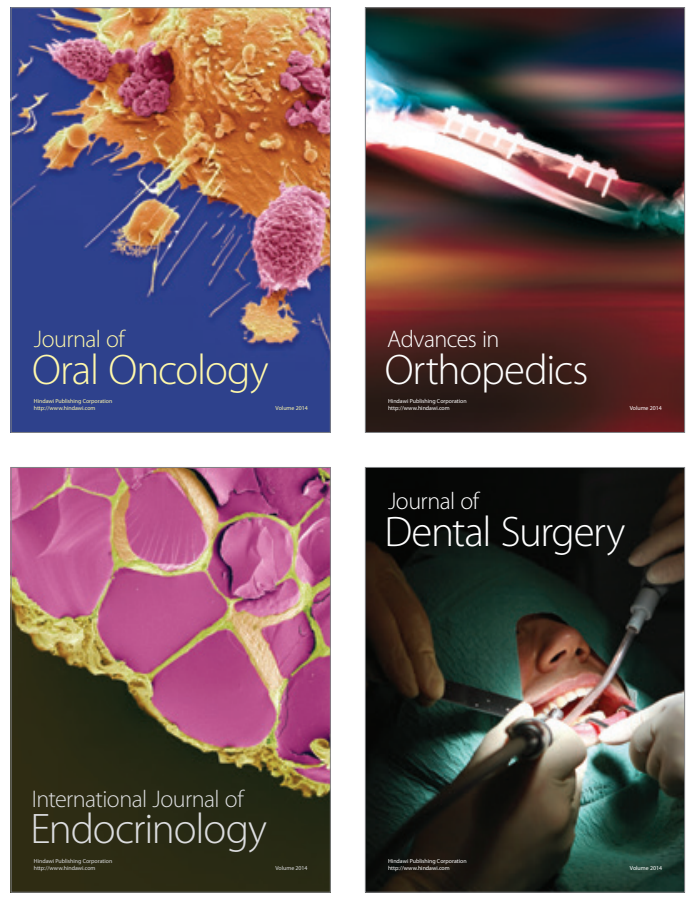
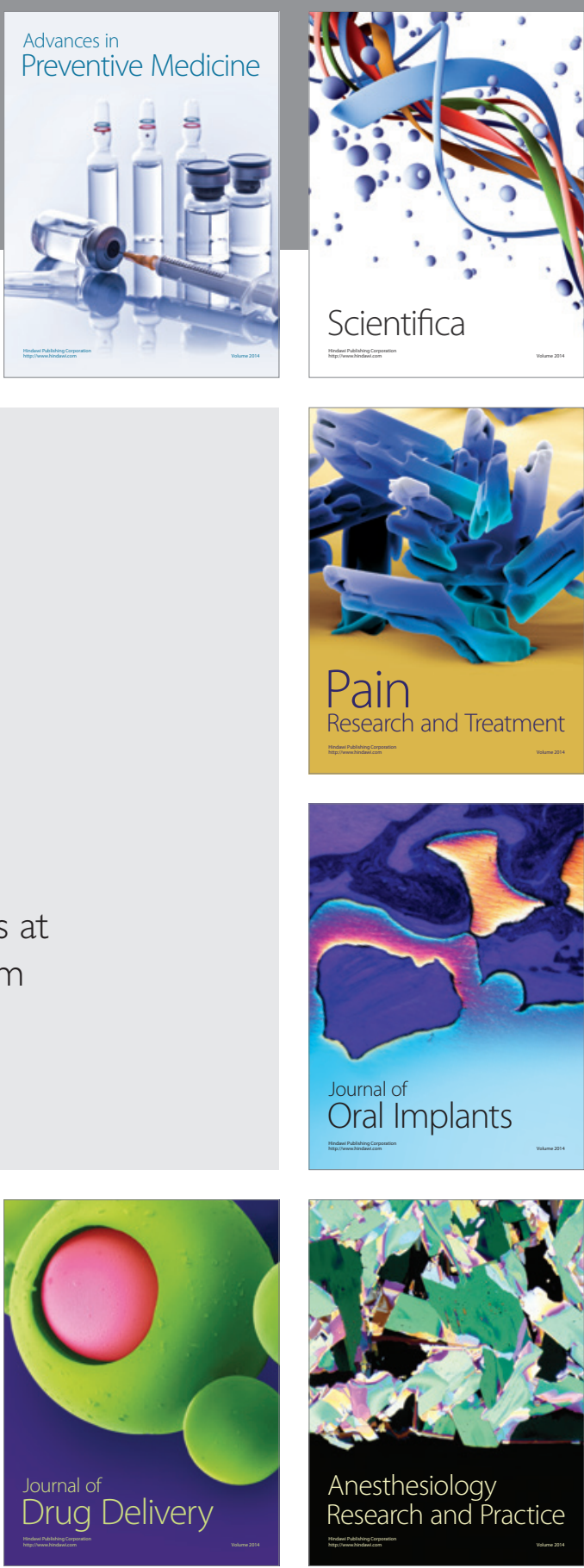

Scientifica
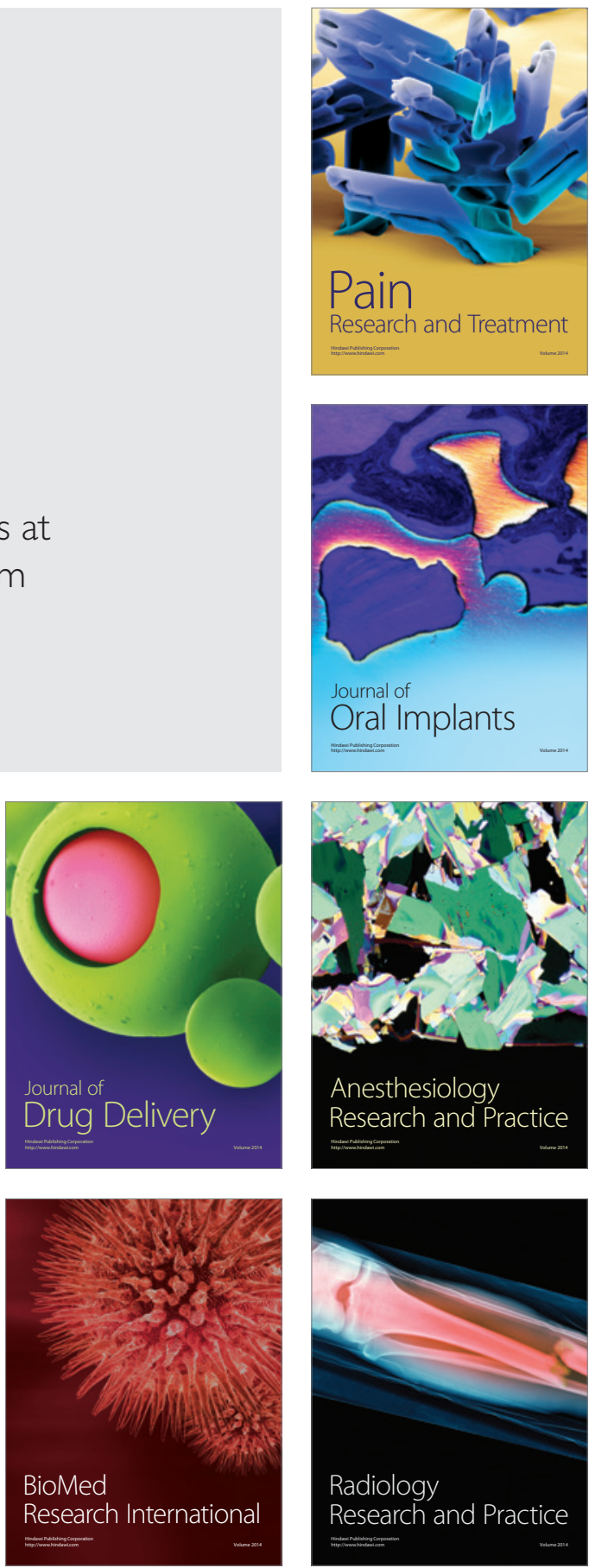